\title{
ASSESSMENT OF THE POSSIBILITY OF REDUCING THE THERMAL LOAD IN THE BARN BY USING MECHANICAL VENTILATION
}

\author{
Jana LENDELOVÁ, Ana HAULIKOVÁ, Miroslav ŽITŇÁK*, Peter KUCHAR \\ Slovak University of Agriculture in Nitra, Slovak Republic
}

\begin{abstract}
The aim of this work is to evaluate possibility of reducing the heat stress of milking cows via climatic indices and the influence of air flow velocity in the object with milking cows using the cross-section method. For the purposes of evaluation, there was selected a four-row housing facility for 160 milking cows with natural ventilation; for the summer period, natural ventilation was supplemented with mechanical ventilation $\left(2877 \mathrm{~m}^{3} \cdot \mathrm{h}^{-1}\right.$ per cow). Measurements were conducted in the network created with 12 measuring points across the barn width, repeated in five cross-sections $A, B, C, D$ and E, followed by further measurements in the longitudinal direction performed always in a row of 22 points placed in resting zones along the air flow direction. Considering the state of potentially high heat load with THI $>78$, it was observed that, according to ETIC, without employing the fans, ETIC in AOZ was higher than $\mathrm{nAOZ}, \mathrm{ETIC}_{\mathrm{AOZ}}=25.34 \pm 0.42 \mathrm{vs} \mathrm{ETIC}_{\mathrm{nOAZ}}=24.51 \pm 0.44(p<0.05)$. After activation of fans above lying area, $\mathrm{ETIC}$ in $\mathrm{AOZ}$ was lower than $\mathrm{nAOZ}, \mathrm{ETIC}_{\mathrm{AOZ}}=23.40 \pm 0.61 \mathrm{vs} \mathrm{ETIC}_{\mathrm{nAOZ}}=23.68 \pm 0.60$, which was not validated in evaluation of THI. Even though the limiting value of very high heat stress ETIC $=25$ was not exceeded after activation of fans, decreasing of heat stress in rest zones did not reach recommended value ETIC $=20$. A more significant improvement was validated in ETIC evaluation with measurements in longitudinal direction in the lying area - there was confirmed dominant influence of air flow speed. Heat load decreasing was influenced by speed and distribution of air in $\mathrm{AOZ}$, both overall and local air exchanges in $\mathrm{AOZ}_{\text {with }} \mathrm{ACH}_{\mathrm{v}}>100 \mathrm{~h}^{-1}$, and barn length.
\end{abstract}

Keywords: temperature - humidity index; equivalent temperature index for cattle; air flow speed; air changes

Hot summer weather in combination with high humidity is unendurable for lactating cows and creates insufferable climate for beef cattle. Furthermore, climate change has also become a major concern for majority of dairy producers (Vaculík et al., 2021). The summer period is generally accompanied with multiple negative effects associated with the severe heat load (Némethová et al., 2020). When air temperature rises from $27^{\circ} \mathrm{C}$ to $32{ }^{\circ} \mathrm{C}$ and relative humidity ranges from $50 \%$ to $90 \%$, the milk production decreases by $10 \%$. Further temperature increase above $32{ }^{\circ} \mathrm{C}$ results in milk production drop by more than $25 \%$ (Fidler and Van Devender, 2016). Heat load does not affect only milk quantity, yet it can affect the quality and composition of milk, protein, fat and lactose contents (Key et al., 2014). High temperatures in summer season have negative impacts on the sexual behaviour of beef cattle, sperm quality or hormonal processes, as well as oestrogen levels, which can afterwards have negative effects on conception. Decrease in conception rate (from $20 \%$ to $27 \%$ ) as a result of heat stress was described by Sheikh et al. (2017). Heat stress can result in slower growth of animals; in more serious cases, it can cause even death of an animal (Das et al., 2016). As a result, all these facts have negative impact on dairy industry and cause considerable economic loss to farmers (Bilby et al., 2008). It is possible to deal with the heat load by direct and indirect cooling (Key et al., 2014; Roth, 2020). Measures to be done to decrease the heat load of milking cows include shading, cooling with fans, accurate air distribution, evaporative cooling, etc. (Becker et al., 2020). Older studies indicate that cooling with forced ventilation lowers respiration rate and improves feed intake (Armstrong, 1994). Forced ventilation together with skin soaking allows animals to cool down, conducting the heat away from animal body (Berman, 2019). Furthermore, according to Brouček et al. (2019), cooling of milking cows through forced ventilation and evaporation has effect on lower heat stress. The authors even highlighted significant differences in milk yield, fat and protein contents between production of cattle cooled with fans and cattle cooled by fans together with evaporative cooling. Forced ventilation influences also cow behaviour. Lendelová et al. (2012) found that milking cows cooled with evaporation (sprinklers) and fans spent longer time lying (10.76 $\mathrm{h} \cdot \mathrm{d}^{-1}$ per cow) in contrast to cattle cooled only by evaporation (7.71 $\mathrm{h} \cdot \mathrm{d}^{-1}$ per cow). Calegari et al. (2014) observed that, in housing object, milking cows preferred areas which were cooled with forced ventilation, they spent more time lying in the ventilated part of barn ( $9.5 \mathrm{~h}$ vs. $8.6 \mathrm{~h}$ ). It is obvious that cooling has a positive effect on milking cows, however, frequency of cooling and soaking type are also considered to be important factors (Frazzi et al., 2000; Pinto et al., 2019). Milking cows under influence of either first or second form of cooling showed better results in rectal 
temperature, respiration rate, higher milk yield, and milk content in contrast to control group which was not cooled. Early detection of heat stress can prevent unfavourable impacts of heat load on milking cows' production (Herbut et al., 2019). These observed parameters are joined in one value in the form of climatic indices. Temperature-humidity index (THI) is used to estimate heat load and it is the most used index (Brown-Brandl, 2018). It combines the air temperature and relative humidity into final value, which is assessed in terms of risk zones (Thom, 1959). The value $\mathrm{THI}=72$ is considered a threshold of thermal neutral zone; all values exceeding it indicate heat stress with deteriorated production parameters of dairy cows (Armstrong, 1994; Akyuz et al., 2010); further categories include mild stress (72< $\mathrm{THI}<79$ ), moderate stress $79<\mathrm{THI}<89$, and severe stress $\mathrm{THI}$ $>89$ (Akyuz et al., 2010). Several authors (Collier et al., 2011; De Rensis et al., 2015) reported even lower threshold value to have such effects, mainly $\mathrm{THI}=68$. Temperature-humidity index takes into account the air temperature and relative humidity of the air, however, it does not consider other microclimatic parameters like air flow velocity and solar radiation (Zhou et al., 2019). An apposite index for evaluation of heat environment is equivalent temperature index for cattle (ETIC), which takes into account the temperature, relative humidity and flow velocity of air, as well as solar radiation (Wang, 2018a), and has determined risk threshold (mild $18 \leq \mathrm{ETIC}<20$, moderate $20 \leq \mathrm{ETIC}<25$, severe $25 \leq \mathrm{ETIC}$ $<31$, emergency $31 \leq \mathrm{ETIC}$ ) (Wang, 2018b). Climatic indices discovered by scientific studies numerically reflect the state of environment which is qualitatively important for provision of appropriate living conditions of animals.

The research presented studies the potential influence of reducing the thermal load in barn utilizing mechanical ventilation in terms of indices of THI, ETIC and intensity of air exchange.

\section{Material and methods}

The research was conducted at a typical four-row housing facility with dimensions of $27.9 \times 69.2 \mathrm{~m}$; a central feed corridor is $4.76 \mathrm{~m}$ wide and movement corridors are situated at the longitudinal circumferential walls (Figs 1 and 2). The object designed for 4 identical groups of dairy cows, each comprising 40 animals, was built as a natural ventilated building (NVB). The floor area is $1930.68 \mathrm{~m}^{2}$, which is $12.07 \mathrm{~m}^{2}$ per cow, taking into account that there are 160 housed animals. With height of $9.1 \mathrm{~m}$, the object has a total volume of $12790.72 \mathrm{~m}^{3}$, which is $79.94 \mathrm{~m}^{2}$ per cow. Barn has a roof (at a slope of $20^{\circ}$ ) insulated with polyurethane agro panels with a continuous ridge ventilation slit that is $67 \mathrm{~m}$ long and 1.15 $\mathrm{m}$ wide. The longitudinal side walls are $1 \mathrm{~m}$ high, and the rest of the opening (up to a height of $4.23 \mathrm{~m}$ ) can be closed with a roller shutter system. Measurements of microclimatic parameters outside and inside the object were performed over two years. In 2019, a natural ventilation system was used in the housing facility; in summer 2020, there was also installed a ventilation system with additional motor ventilation with 10 cyclone fans, each with an output of $46031 \mathrm{~m}^{3} \cdot \mathrm{h}^{-1}$ (the overall output was $460310 \mathrm{~m}^{3} \cdot \mathrm{h}^{-1}$ ) in order to reduce the heat load in summer.

To monitor the climatic situation in summers of 2019 and 2020, continuous measurements of microclimatic parameters of air temperature, relative humidity and air flow rate were performed. The COMET S-3121 devices were used for long-term measurement of air temperature and relative humidity, the TestoVent 06995100 device was used for continuous measurement of air flow rate (at permanent measurement sites P1, P2, P3 according to the diagram in Fig. 2). On selected days, ambulant measurements were performed when the air temperature exceeded $30^{\circ} \mathrm{C}$ and the flow velocity did not exceed $2 \mathrm{~m} \cdot \mathrm{s}^{-1}$. The measurements were

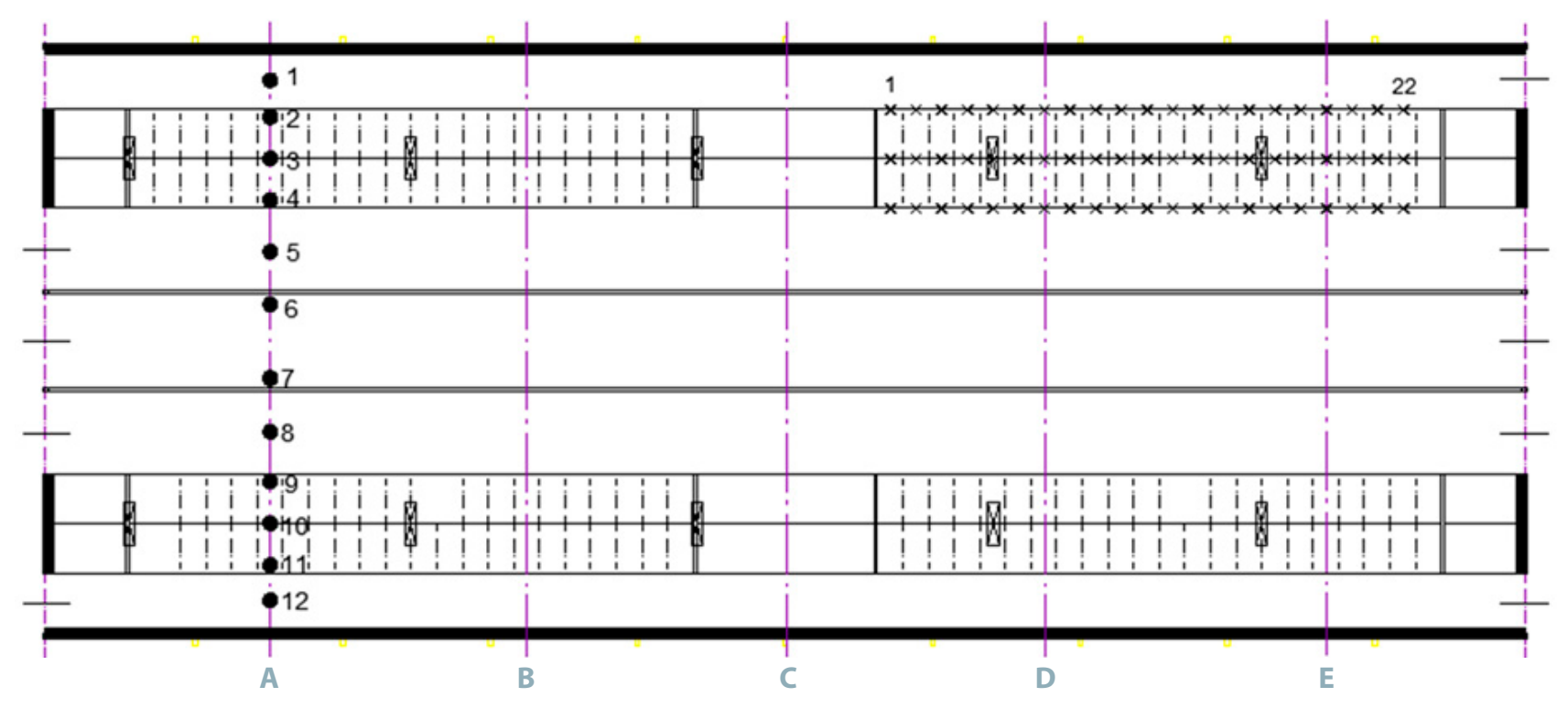

Fig. 1 Object floor plan with measuring points arranged in five cross-sections (always with the same positions of measuring points from 1 to 12 across the width of the building) and in the longitudinal direction from place 1 to 22 parallel to the air flow 


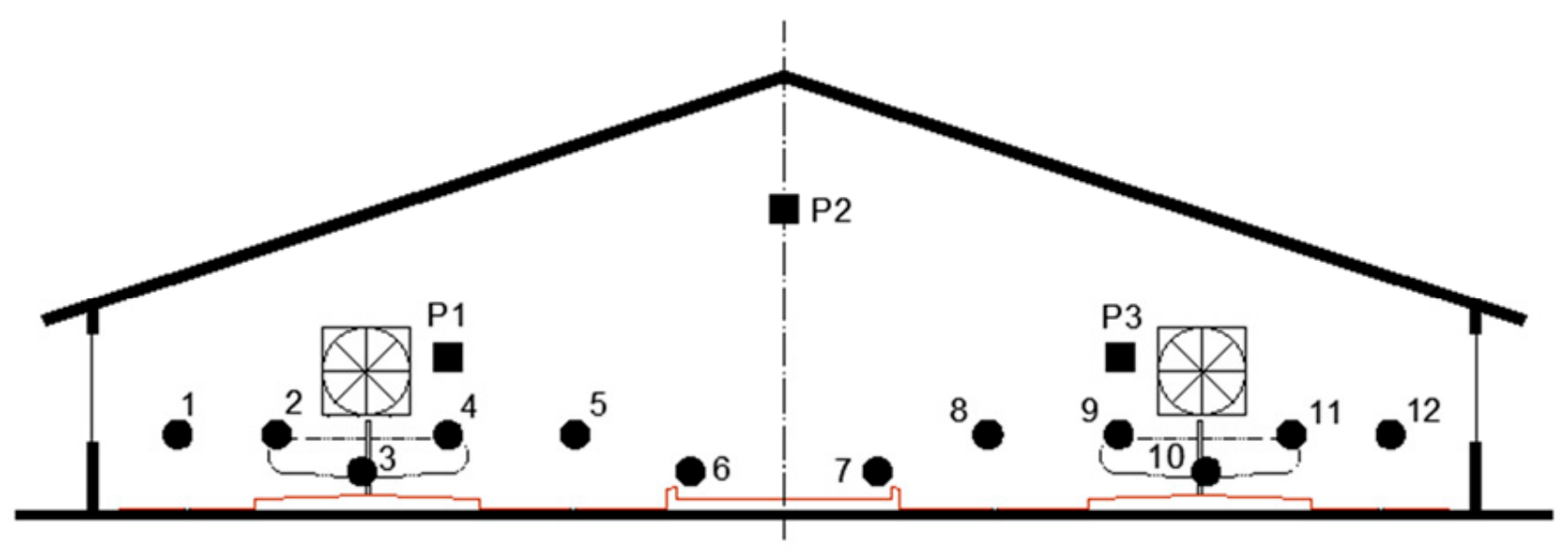

Fig. 2 Cross-section of the housing facility with measuring points of daily ambulatory measurements

$\mathrm{T}_{\text {int }}$ - air temperature; $\mathrm{RH}_{\text {int }}$ - relative humidity; $\mathrm{v}_{\text {int }}$ - flow velocity; $\mathrm{sr}_{\text {int }}-$ solar radiation at the height level of standing animals (places no. $1,2,4,5$ and $8,9,11$ and 12 at the height of $1,300 \mathrm{~mm}$ from the floor) and the measuring points at the level of head of either lying or eating animals (points 3, 6,7 and 10 at the height of $500 \mathrm{~mm}$ from the floor). Such a distribution of measuring points was always used in the same way in the cross-section $A, B, C, D$ and $E$ (Fig 1). Points $P 1, P 2$ and $P 3$ are places of permanent measurements: $T_{\text {int, }}$ - indoor air temperature; $\mathrm{RH}_{\text {int, }}$ - relative humidity; $\mathrm{v}_{\text {int, }}$ - air flow velocity

generally performed at the same time from 13:00 to 17:00. The methodology of daily ambulant measurements was always identical. Twelve measurement sites were identified, equally located in each cross-section and each passing from point 1 to 12 . The measurement time at each site was 3 minutes and the recording frequency was 5 seconds. The same procedure was followed in five profiles $A, B, C, D, E$, which together represented a network of 60 measurement sites. At measuring points no. 1, 2, 4, 5 and 8, 9, 11 and 12, the measurements were performed at the level of $1,300 \mathrm{~mm}$ from the floor (in the height of the standing animals). At points no. 3, 6, 7 and 10, the measurements took place at a height of $500 \mathrm{~mm}$ from the floor (height of the head of lying or eating animals). Further measurements along the building and inside the individual cubicles took place at a height of $500 \mathrm{~mm}$ and 1,300 $\mathrm{mm}$ from the floor. Twentytwo measurement sites were determined for each group of dairy cows (Fig. 1). The development of climatic indices was evaluated not only for the entire building, but also for the zone occupied by animals (AOZ) taking into account the data from points $1,2,3,5,8,9,10,11,12$; for the zone not occupied by animals (nOAZ), the data were taken from points 6 and 7. The ALMEMO 2590-4S device was used for ambulant measurements of air temperature, relative humidity and flow rate. The KIMO SL 100 device was used to measure solar radiation.

In the calculation part, the following equations were used for selected climatic markers - THI and ETIC (calculations of indices were based on Fournel et al. (2017) according to Kelly and Bond (1971) and Wang et al. (2018a)).

$$
\mathrm{THI}=(1.8 \times T d b+32)-((0.55-0.0055 \times R H) \times
$$$$
(1.8 \times T d b-26.8))
$$

where:

$T d b$ - dry bulb temperature $\left({ }^{\circ} \mathrm{C}\right) ; R H$ - relative humidity (\%) (Kelly and Bond, 1971)

$$
\begin{aligned}
\mathrm{ETIC}= & T d b-0.0038 \times T d b \times(100-R H)-0.1173|v|^{0.707} \times \\
& \times(39.2-T d b)+1.86 \times 10^{-4} \times T d b \times s r
\end{aligned}
$$

where:

$T d b$ - temperature measured by a dry bulb thermometer $\left({ }^{\circ} \mathrm{C}\right) ; R H$ - relative humidity (\%); $v$ - air flow rate $\left(\mathrm{m} \cdot \mathrm{s}^{-1}\right) ; \mathrm{sr}-$ solar radiation $\left(\mathrm{W} \cdot \mathrm{m}^{-2}\right.$ ) (Wang et al., 2018a)

Subsequently, the air exchange rate $(A C H), \mathrm{h}^{-1}$, was calculated as follows:

$$
A C H=\frac{Q}{V}=\frac{V \times P}{V}
$$

where:

$Q$ - air flow rate $\left(\mathrm{m}^{3} \cdot \mathrm{h}^{-1}\right) ; V$ - object volume $\left(\mathrm{m}^{3}\right) ; v$ - air flow velocity $\left(\mathrm{m} \cdot \mathrm{h}^{-1}\right) ; P$ - cross-sectional area of object (locality) perpendicular to the direction of air flow $\left(\mathrm{m}^{2}\right)$

The data were processed using the STATISTICA ver. 10 software for basic variation-statistical characteristics, onefactor and multi-factor analysis of variance. The significance of differences in the indices monitored was tested by Tukey's contrast test.

\section{Results and discussion}

The evaluation results of $\mathrm{THI}$ for $\mathrm{AOZ}$ and $\mathrm{nAOZ}$ in the state with and without fans are shown in Figs $3 a$ and $3 \mathrm{~b}$. It was observed that THI did not show any improvement between zones even after employment of motor ventilation (Fig. 3b), in both cases, there was a severe heat load in $\mathrm{AOZ}$ ( $\mathrm{THI}>78$ ).

The ETIC results in the state with natural ventilation (Fig. 3c) - without additional fans - point to a worse state demonstrated by higher values of ETIC $=25.34$ in the animal zone due to heat and humidity produced in $\mathrm{AOZ}$ and low flow rates in this space without fans. There was found a significant decrease in ETIC $(p<0.05)$ in AOZ after fan 


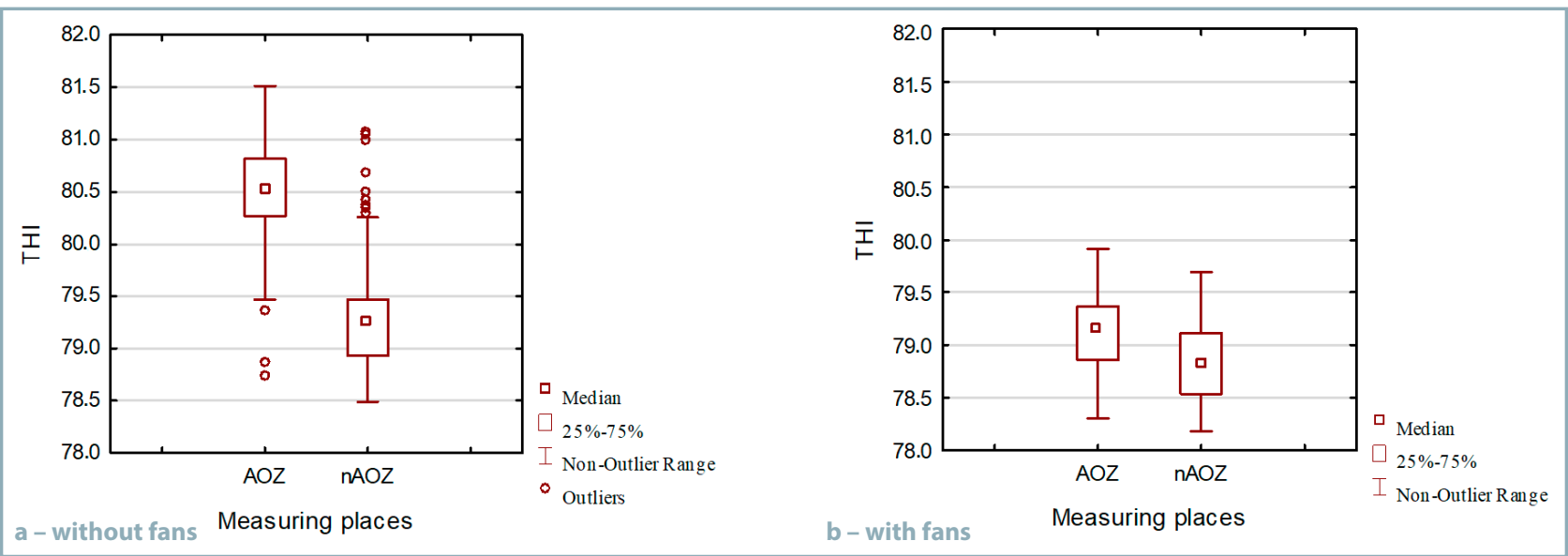

Fig. $3 a-$ THI results with natural ventilation without additional fans; $b-$ THI results with additional motor ventilation

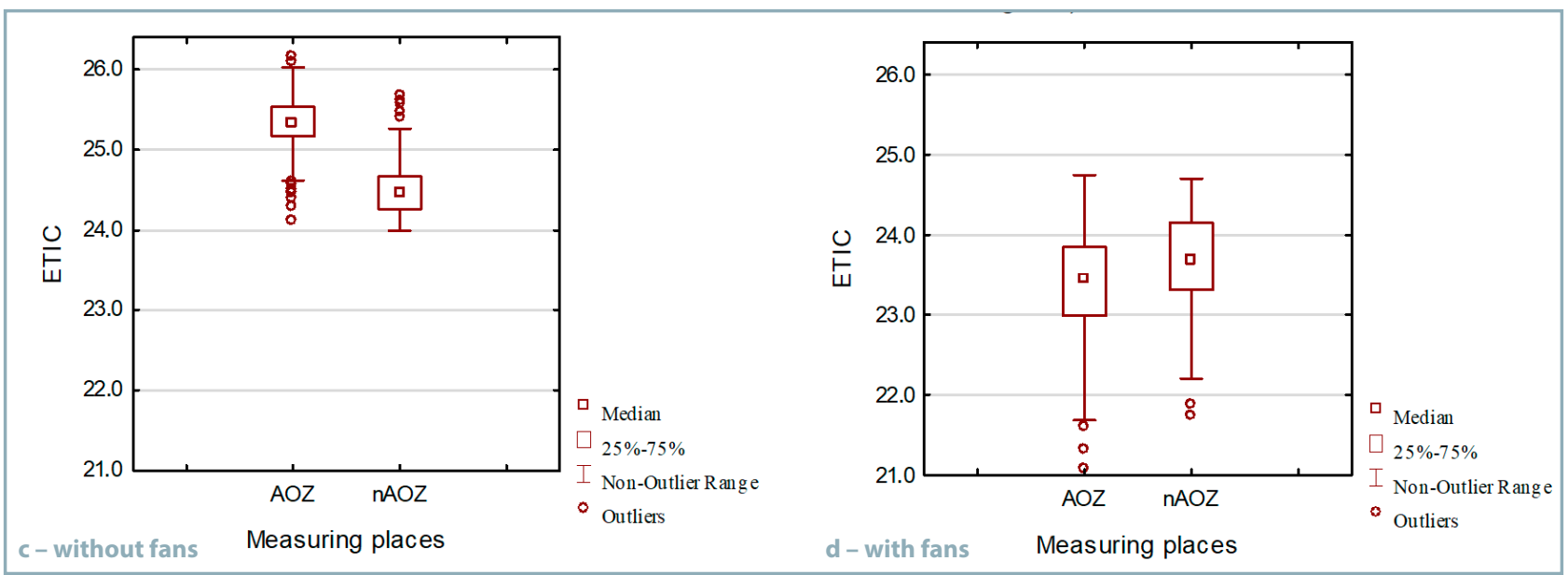

Fig. 3 c-ETIC with natural ventilation without additional fans; d-ETIC with additional motor ventilation

employment (Fig. 3d), resulting in a significant difference between $\mathrm{AOZ}$ and $\mathrm{nAOZ}$ : $\mathrm{ETIC}_{\mathrm{AOZ}}=23.40 \pm 0.61 \mathrm{vs} \mathrm{ETIC}_{\mathrm{nAOZ}}=$ $23.68 \pm 0.60$, declaring an even better environment in AOZ.

The results of a more detailed analysis of THI and ETIC based on measurements in cross-sections with employed fans are shown in Figs $4 \mathrm{a}$ and $4 \mathrm{~b}$. In places of direct reach of fan flow $(2,3,4,9,10,11)$, no significant differences in THI were observed in comparison with movement corridors in their immediate vicinity $(1,5,8,12)$. Paradoxically, the best $\mathrm{THI}$ condition was recorded in the fanless state.

It was found that $\mathrm{TH}$ reacts negatively to the animal zone and does not capture changes in the area with installed fans. Without fans, ETIC results exceeded the limit of ETIC = 25 (Fig. 3c), indicating a strong heat load; however, with employed fans, ETIC values showed a significant reduction in heat load, especially in beds - in 2, 3, 4, 9, 10 and 11 where the fans were located (Fig. 4b). By comparing the ETIC measured in beds $(2,3,4,9,10,11$ (ETIC lying $)$ ) and data measured in movement corridors $\left(1,5,8,12\right.$ (ETIC mooving $\left._{1}\right)$ in cross-sections $A, B, C, D$ and $E$ with activated fans, there was observed a reduction in the heat load in the lying area in contrast to the movement corridors: $\mathrm{ETIC}_{\text {lying, }}$ avg $=23.18 \mathrm{vs}$. $\mathrm{ETIC}_{\text {mooving, }}$ avg $=23.72$.

When evaluating ETIC and ACH (Figs $5 a$ and $5 b$ ) in the longitudinal direction (parallel to the air flow from fans always from the $1^{\text {st }}$ to the $22^{\text {nd }}$ place directly), there was found the largest reduction in the heat load - most frequently in the area from the $2^{\text {nd }}$ to the $5^{\text {th }}$ place from fan (Fig. 5a), where the highest ACH was also recorded (Fig. 5b).

High temperatures adversely affect the dairy housing facility microclimate. During this research conducted in 2019 and 2020 from May to September, there was more than 73 or 76 days with a $\mathrm{THI}>72$, which is consistent with Brouček et al. (2018). Several authors (Collier et al., 2011; Pinto et al., 2019) reported the risks associated with the heat load of dairy cows already at values exceeding $\mathrm{THI}=68$. Selected days, when the average daily indoor air temperatures of the housing facility were $\mathrm{T}_{\text {avg }}=30.79{ }^{\circ} \mathrm{C}$ and $\mathrm{T}_{\text {avg }}=30.35^{\circ} \mathrm{C}$, can be classified as tropical.

Under such conditions, an increase in rectal temperature and respiration rate is evident; moreover, feed intake decreases, resulting in a decrease in milk production (Wheelock et al., 2010; Galán et al., 2018). Recent studies point to a constant reducing of temperature limits of tolerable heat load associated with health status and production parameters - the negative impacts of heat stress on the amount and composition of milk are usually evident after 2 or 4 days of exposure to it (Bernabucci et al., 2014). Therefore, timely and accurate detection of heat stress in cattle is essential. During the summer period, from May to 


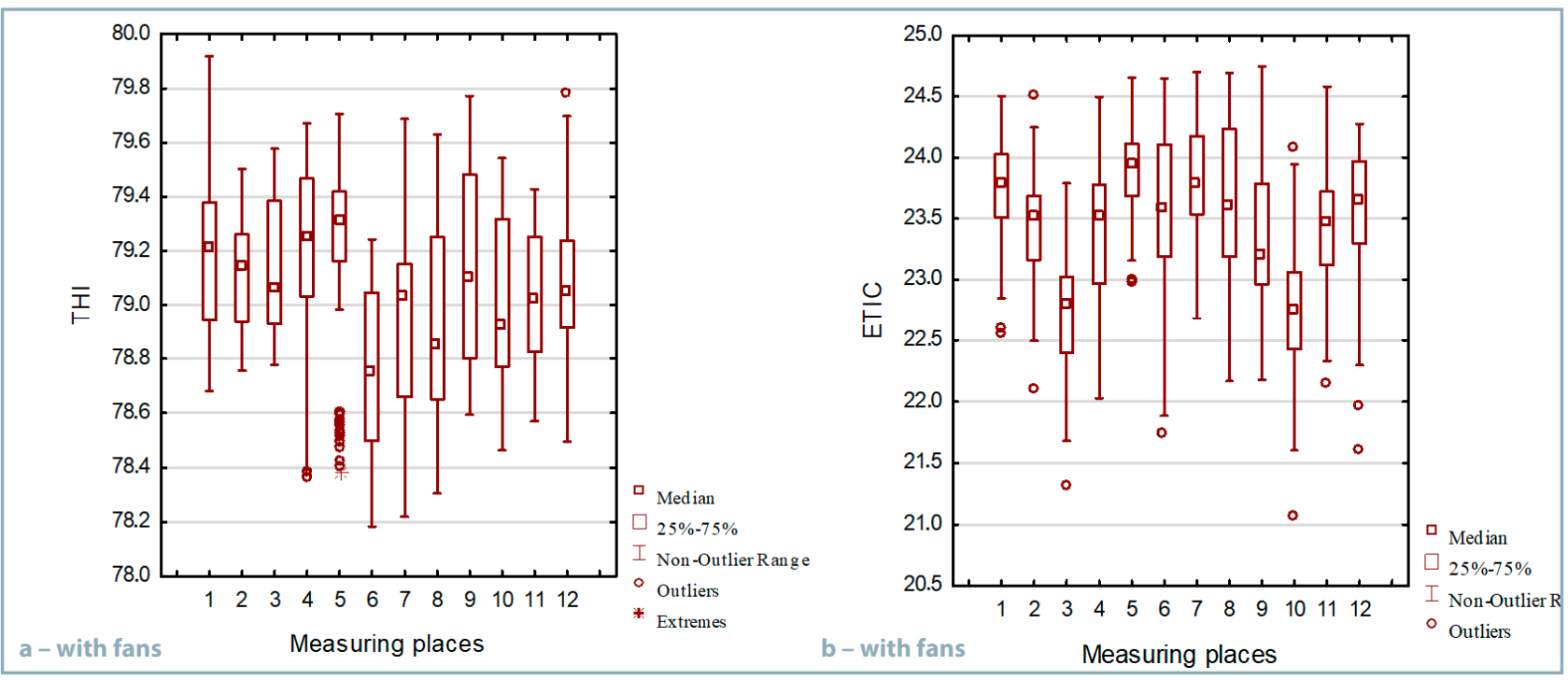

Fig. 4 a - THI results for activated fans using measurement points 1-12 in five cross-sections; $b$ - ETIC results for activated fans using measurement points $1-12$ in five cross-sections

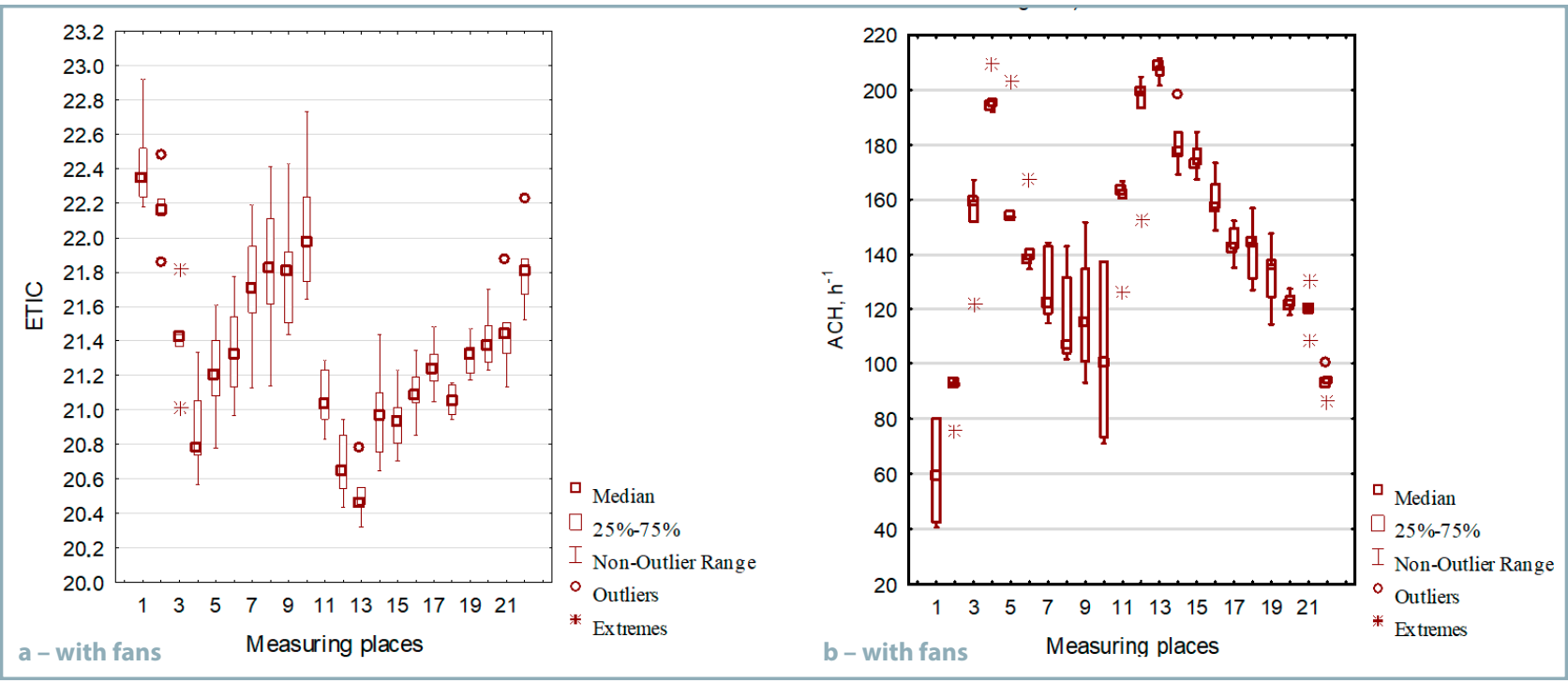

Fig. 5 a - ETIC evaluation in the longitudinal direction with activated fans using measuring points 1-22 arranged in the longitudinal direction; $\mathrm{b}-\mathrm{ACH}$ evaluation in the longitudinal direction with activated fans using measuring points 1-22 arranged in the longitudinal direction

September, it is recommended to monitor the THI values in order to prevent health issues and reduced milk yield in dairy cows (Akyuz et al., 2010). Based on the monitoring conducted by our research institute, the risk of excessive heat load due to the climatic situation in the lowlands of Slovakia is evident and recurring every year for at least four months.

The combination of high air temperature and high relative humidity adversely affects the removal of excess heat in dairy cows (West et al., 2003). The average relative humidity on selected days in 2019 and 2020 were $\mathrm{RH}_{\mathrm{avg}}=$ $54.87 \%$ and $\mathrm{RH}_{\text {avg }}=50.47 \%$, respectively. During selected measurements, the mean THI exceeded the limit THI $>78$ in period from 13:00 PM to 17:00 PM. In experimental stable, $\mathrm{THI}_{\mathrm{avg}}=80.32$ and $\mathrm{THI}_{\mathrm{avg}}=79.05$, representing a serious stress for dairy cows. Nordlund et al. (2019) observed that an increase in THI to a THI level more than 78 caused the cows to spend less time in the rest zone and decreased the lying time from $9.5 \mathrm{~h}$ to $6.2 \mathrm{~h}$.

There were conducted evaluations of the microclimatic parameters of the air under similar conditions $\mathrm{THI}_{\mathrm{avg}}=79.58$ \pm 0.59 in experimental stable for two conditions. The NVB condition without installed fans, when the air flow in the stable was affected only by accidental external wind events; and temperature/pressure difference, i.e., the condition without motor ventilation. On days without significant external wind (up to the $2^{\text {nd }}$ degree of the Beaufort scale) the movement of air masses was minimal $\left(v_{a v g}=0.20 \mathrm{~m} \cdot \mathrm{s}^{-1}\right.$ \pm 0.08 ) and the normal air flow regime was very calm with flow velocities in less than $0.5 \mathrm{~m} \cdot \mathrm{s}^{-1}$, usually windless at less than $0.25 \mathrm{~m} \cdot \mathrm{s}^{-1}$, which is consistent with Wheeler (2012). Thanks to ventilation, it is possible to improve the air quality 
of housing facilities in the form of extracting the heat, moisture and harmful gases (Drewry et al., 2018); however, it is important to opt for suitable unit fan capacity, airflow distribution options and construction parameters. There is a questionable limit to the effective increase in the air flow speed, which, on the other hand, also leads to an increase in dust, noise, etc. By installing 10 fans in rest areas, each with an output of $46031 \mathrm{~m}^{3} \cdot \mathrm{h}^{-1}$ with large-area adjustable guide lamellas, and tilting them to the animal zone, the movement of air masses in the experimental object was significantly increased, $v_{\max }=4.11 \mathrm{~m} \cdot \mathrm{s}^{-1}$ was observed in the axis of fans in each group. The highest values usually occurred in cubicles 2 to 5 from the fan position. Although in other cubicles the speed was gradually decreasing, sufficient air distribution with speeds of $1.0 \mathrm{~m} \cdot \mathrm{s}^{-1}<v<3.0 \mathrm{~m} \cdot \mathrm{s}^{-1}$ was reliably secured by lamellas in all beds (after installing the fans, the average speed was $v_{\text {avg }}=2.74 \pm 0.75 \mathrm{~m} \cdot \mathrm{s}^{-1}$ ). The cubicle occupancy and cattle position in the movement corridors then influenced the regime of air flow in the adjacent areas. The air flow distribution is complicated because the air flow patterns are not uniform throughout the housing (Bustos-Venegas et al., 2019).

However, it is impossible to properly interpret the changes in the heat load affected by changes in the actually measured flow rates enhanced by the motor ventilation by calculating the $\mathrm{THI}$, as it takes into account only the air temperature and relative humidity and other microclimatic parameters, such as air flow rate and solar radiation, are reflected only indirectly (Lees et al., 2018). For a more thorough air quality assessment of the housing facility and individual barn areas, the ETIC was utilized for the evaluation of indoor environment quality.

In transverse profiles from $\mathrm{A}-\mathrm{E}$, there were measured values of $E T I C_{a v g}=25.17$ without fans and $E{ } C_{a v g}=23.44$ with activated fans. The highest flow velocity was recorded in the rows above which the fans were suspended $\left(E T I C_{\min }=20.94\right)$. Guides (Zhou et al., 2019) could be helpful in improving the cooling effect of fans. The researchers found that, in objects with installed baffles, the current flow increased from 0.5 to $3 \mathrm{~m} \cdot \mathrm{s}^{-1}$ (Zhou et al., 2019), similarly as reported by Harner and Smith (2008): from 0.89-1.34 $\mathrm{m} \cdot \mathrm{s}^{-1}$ to $2.68-3.58 \mathrm{~m} \cdot \mathrm{s}^{-1}$. The instalment of baffles showed a reduction in ETIC of 5 units (Zhou et al., 2019). The air flowing in the upper space of barn was directed to the animal zone thanks to the rectifiers. The cooling effect of rectifiers was confirmed by ETIC in this study, however, it is necessary to point out that they were tested at a lower THI occurring during our experimental measurements. According to Mondaca et al. (2019), increasing the air flow rate alone is not a sufficient solution, as more than $2 / 3$ of air usually does not reach the animal zone.

According to the measurements performed, it appears that the occurrence of the highest heat load was associated with high THI and low air flow rates, so the most important is the ability of air masses to dissipate the heat and pollutants produced. The recommended air change for dairy cows is usually from 30 to 60 air changes per hour (Mondaca et al., 2019).

Based on the measurements conducted in crosssections, $\mathrm{ACH}_{\mathrm{avg}}=68.01 \pm 44.11 \mathrm{~h}^{-1}$; there was obtained $\mathrm{ACH}_{\mathrm{avg}}=140.82 \pm 38.82 \mathrm{~h}^{-1}$ in longitudinal measurements.
However, the type of ventilation (general or localized method) is important, as is the type of air exchange assessment (general or localized). On the basis of the total air exchange observed in this research, $A_{C H} H_{\text {total }}=33.69 \mathrm{~h}^{-1}$. When calculating the air exchange for individual areas, it was found that the evaluation process and the required $\mathrm{ACH}$ limits need to be modified. According to the measurements in cross-sections, the local air exchange was $\mathrm{ACH}=42.99 \mathrm{~h}^{-1}$ in the zone unoccupied by animals (feed corridor) and $\mathrm{ACH}=103.01 \mathrm{~h}^{-1}$ in the zone occupied by animals.

For the dairy rest zone, it is recommended to introduce an assessment for the area of the directed air flow calculated up to a theoretical height of $2.0 \mathrm{~m}$ and the associated flow and volume calculations. The results show that the required local air exchange in the animal rest area for $\mathrm{THI}>78$ should be $\mathrm{ACH}$ from 100 to $150 \mathrm{~h}^{-1}$. If such a value is to be achieved in the majority of cubicles, a suitable distribution of air by means of lamellas and baffles must be ensured. Concurrently, it is necessary to accept that, in certain cubicles, there will be individual flow velocities with $v>3 \mathrm{~m} \cdot \mathrm{s}^{-1}$.

The results of cross-method measurements pointed out a range of areas and various cases of air mass displacement. In the areas where the fans were installed, the air exchange reached almost twice the rate of the feed corridor.

The air masses under fans at a height of $1,300 \mathrm{~mm}$ moved in areas from 1 to 22 at speeds $v_{\min }=0.79 \mathrm{~m} \cdot \mathrm{s}^{-1}$ to $v_{\max }=4.11 \mathrm{~m} \cdot \mathrm{s}^{-1}$, which significantly affected the air exchange. The air exchange was also affected by the local velocities measured in the transverse profiles at points 1 to 12. Since the air exchange calculation is also affected by the object geometry, there was developed a case simulation of the interdependence of flow rate, object length and air exchange (Fig. 6). It is clear from the results that, for this experimental object with a length of approx. $70 \mathrm{~m}$, an air exchange of $100 \mathrm{~h}^{-1}$ was achieved at an average flow velocity $v=2.0 \mathrm{~m} \cdot \mathrm{s}^{-1}$. If the object was $130 \mathrm{~m}$ long, it would be necessary to achieve an average speed of $v=4.0 \mathrm{~m} \cdot \mathrm{s}^{-1}$ to

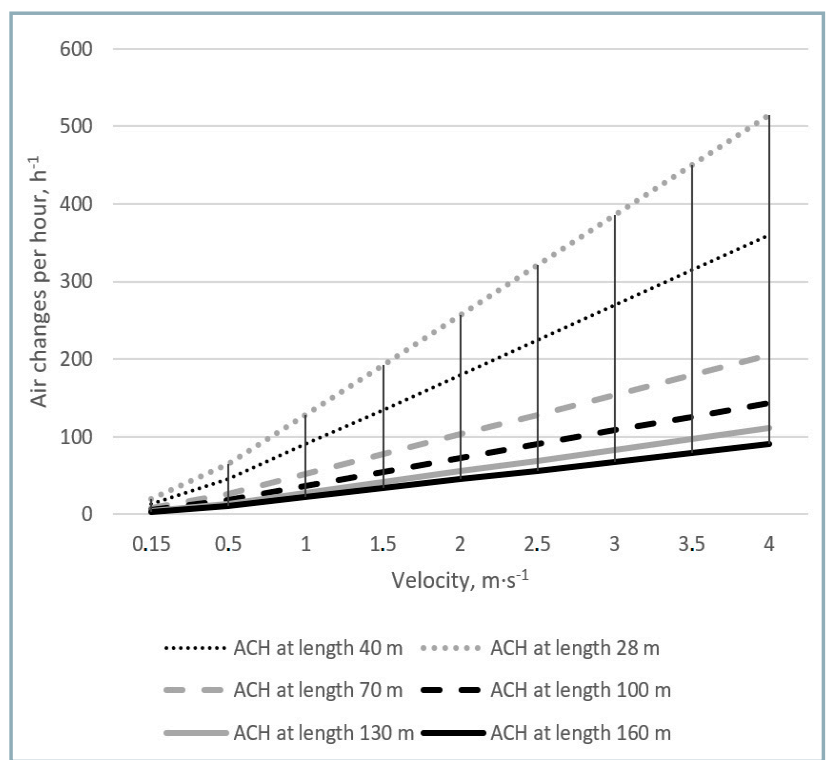

Fig. 6 Results of case simulations of the air exchange intensity depending on the air flow rate at different object lengths 
ensure the same air exchange. For smaller objects, the air flow rate demands are reduced for the air exchange to be more efficient.

\section{Conclusions}

Excessive heat load in the summer has a negative impact on the health of dairy cows and the economic profitability of breeding, even in climatic conditions of Slovakia. The most frequent facilities for dairy cows constructed only with natural ventilation (NVB) usually need suitable modifications of the breeding environment in summer. Instalment of additional fans is often used to speed up the air movement. On the basis of evaluation of the environment state without fans and after their installation $\left(2877 \mathrm{~m}^{3} \cdot \mathrm{h}^{-1}\right.$ per cow), it was found that:

1. In the experimental four-row NVB for 160 dairy cows (with volume and area parameters: $79.94 \mathrm{~m}^{3}$ per cow and $12.07 \mathrm{~m}^{2}$ per cow) in an environment with $\mathrm{THI}>78$ without activated fans, ETIC in AOZ is higher than in $\mathrm{nAOZ}, \mathrm{ETIC}_{\mathrm{AOZ}}=25.34 \pm 0.42$ vs. $\mathrm{ETIC}_{\mathrm{nAOZ}}=24.51 \pm 0.44$ $(p<0.05)$. After activating the supernatants, the ETIC in $\mathrm{AOZ}$ was lower than in $\mathrm{nAOZ}, \mathrm{ETIC}_{\mathrm{AOZ}}=23.40 \pm 0.61 \mathrm{vs}$. $\mathrm{ETIC}_{\mathrm{nAOZ}}=23.68 \pm 0.60$.

2. At THI >78, ETIC was in the risk level from 25 to 30 in all AOZ places without fans; with activattion of 10 fans (each with a capacity of $46031 \mathrm{~m}^{3} \cdot \mathrm{h}^{-1}$ ), the risk level was from 20 to 25.

3. Based on the measurements from points in cross-section, at $\mathrm{THI}>78$, ETIC was significantly lower in the rest zone with activated fans than in movement zones $\left(\mathrm{ETIC}_{\text {lying }}=\right.$ 23.18 compared to $\left.E T I C_{\text {mooving }}=23.72\right)$, but $E T I C=20$ was not reached $\left(E T I C_{\min }=21.07\right.$ in the transverse direction and $\mathrm{ETIC}_{\min }=20.94$ in the longitudinal direction).

4. Local air exchange evaluated by the detailed crossmethod indicated a suitable environment in AOZ; based on the assessment of transversely arranged measuring points, $\mathrm{ACH}_{\mathrm{v}}=68.01 \pm 44.15 \mathrm{~h}^{-1}, \mathrm{ACH}_{\mathrm{v}}=140.82 \pm 38.82 \mathrm{~h}^{-1}$ based on the evaluation of rest zone in the longitudinal direction.

5. The evaluation of ETIC at temperatures $\mathrm{T}>28{ }^{\circ} \mathrm{C}$ and relative air humidity $R H>35 \%$ in an experimental object with a unit output Qj $=2877 \mathrm{~m}^{3} \cdot \mathrm{h}^{-1}$ per cow showed that the environment quality in animal zone can be significantly improved by mechanical ventilation ensuring local air exchange in the animal rest zone at the level of $100 \mathrm{~h}^{-1}<\mathrm{ACH}<150 \mathrm{~h}^{-1}$, at which the velocity of the directed air flow in animal zone would be increased to the range of $1.0<v<3.0 \mathrm{~m} \cdot \mathrm{s}^{-1}(\Delta \mathrm{ETIC}$ avg $\geq-1.3)$ with local occurrences of higher velocities $\left(v>3.0 \mathrm{~m} \cdot \mathrm{s}^{-1}\right)$.

6. In order to achieve the ETIC $=20$ limit value across the entire object, a further increase in ventilation power, a more precise distribution of the driven air, or the involvement of another method of cooling the dairy cows would be necessary.

\section{Acknowledgements}

This publication was supported by the Operational Programme Integrated Infrastructure within the project: Sustainable Smart Farming Systems Taking into Account the Future Challenges 313011W112, co-financed by the European Regional Development Fund.

\section{References}

AKYUZ, A. - BOYACI, S. - ÇAYLI, A. 2010. Determination of critical period for dairy cows using temperature humidity index. In Journal of Animal and Veterinary Advances, vol. 9, no. 13, pp. 1824-1827.

ARMSTRONG, D. V. 1994. Heat stress interaction with shade and cooling. In Journal of Dairy Science, vol. 77, no. 7, pp. 2044 -2050.

BECKER, C. A. - COLLIER, R. J. - STONE, A. E. 2020 Invited review: physiological and behavioral effects of heat stress in dairy cows. In Journal of Dairy Science, vol. 103, no. 8, pp. 6751-6770.

BERMAN, A. 2019. An overview of heat stress relief with global warming in perspective. In International Journal of Biometeorology, vol. 63, pp. 493-498

BERNABUCCI, U. - BIFFANI, S. - BUGGIOTTI, L. - VITLI, A. - LACETERA, N. - NARDONE, A. 2014. The effects of heat stress in Italian Holstein dairy cattle. In Journal of Dairy Science, vol. 97, no. 1, pp. 471-486.

BILBY, T. R. - BAUMGARD, L. H. - COLLIER, R. J. - ZIMBELMAN, R. B. RHOADS, M. L. 2008. Heat stress effects on fertility: Consequences and possible solutions. In The Proceedings of the 2008 South Western Nutritional Conference.

BROUČEK, J. - RYBA, Š. - DIANOVÁ, M. - UHRINČAŤ, M. - ŠOCH, M. HANUS, A. - ZABRANSKÝ, L. 2018. Herd-level production impacts of evaporative cooling of dairy cows on milk production in Slovakian lowlands. In $10^{\text {th }}$ International Livestock Environment Symposium (ILES X), Paper no: ILES18-039.

BROUČEK, J. - RYBA, Š. - DIANOVÁ, M. - UHRINČAŤ, M. - ŠOCH, M. ŠíSTKOVÁ, M. - MALA, G. - NOVÁK, P. 2019. Effect of evaporative cooling and altitude on dairy cow's milk efficiency in lowlands. In International Journal of Biometeorology, vol. 64, pp. 433-444.

BROWN-BRANDL, T. M. 2018. Understanding heat stress in beef cattle. In Revista Brasileira de Zootecnia Brazilian. In Journal of Animal Science, vol. 47, paper no. e20160414.

BUSTOS-VANEGAS, J. D. - HEMPEL, S. - JANKE, D. - DOUMBIA, M. - STRENG, J. - AMON, T. 2019. Numerical simulation of airflow in animal occupied zones in a dairy cattle building. In Biosystems Engineering, vol. 186, pp. 100-105.

CALEGARI, F. - CALAMARI, L. - FRAZZI, E. 2014. Fan cooling of the resting area in a free stalls dairy barn. In International Journal of Biometeorology, vol. 58, no. 6, pp. 1225-1236.

COLLIER, R. - ZIMBELMAN, R. B. - RHOADS, R. P. - RHOADS, M. L. - BAUMGARD, L. H. 2011. A re-evaluation of the impact of temperature humidity index (THI) and black globe humidity index (BGHI) on milk production in high producing dairy cows. In Western Dairy Management Conference Reno, pp. 113-125.

DAS, R. - SAILO, L. - VERMA, N. - BHARTI, P. - SAIKIA, J. - IMTIWATI KUMAR, R. 2016. Impact of heat stress on health and performance of dairy animals: A review. In Veterinary World, vol. 9. no. 3, pp. 260-268.

DE RENSIS, F. I. - GARCIA-ISPIERTO, I. - LÓPEZ-GATIUS, F. 2015. Seasonal heat stress: Clinical implications and hormone treatments for the fertility of dairy cows. In Theriogenology, vol. 84, no. 5, pp. 659-666.

DREWRY, J. L. - MONDACA, M. R. - LUCK, B. D. - CHOI, C. Y. 2018. A computational fluid dynamics model of biological heat and gas generation in a dairy holding area. In Transactions of the ASABE, vol. 61, no. 2, pp. 449-460.

FIDLER, A. P. - VAN DEVENDER, K. 2016. Heat Stress in Dairy Cattle. Little Rock : University of Arkansas, United States Department of Agriculture, and County Governments Cooperating. Available at: https://www.uaex.edu/publications/pdf/fsa-3040.pdf 
FOURNEL, S. - OUELLET, V. - CHARBONNEAU, É. 2017. Practices for alleviating heat stress of dairy cows in humid continental climates: a literature review. In Animals, vol. 7, no. 5, pp. 37.

FRAZZI, E. - CALAMARI, L. - CALEGARI, F. - STEFANINI, L. 2000. Behavior of dairy cows with different barn cooling systems during the summer. In Transaction of the ASAE, vol. 43, no. 2, pp. 387-394. GALÁN, E. - LLONCH, P. - VILLAGRÁ, A. - LEVIT, H. - PINTO, S. - DEL PRADO, A. 2018. A systematic review of non-productivity-related animal-based indicators of heat stress resilience in dairy cattle. In Plos One, vol. 13, no. 11, article no. e0206520.

HARNER, J. P. - SMITH, J. 2008. Low-profile cross-ventilated freestall facilities - A 2 year summary. In Proceedings of the High Plains Dairy Conference, pp. 65-78.

HERBUT, P. - ANGRECKA S. - GODYŃ, D. - HOFFMANNN, G. 2019 The physiological and productivity effects of heat stress in cattle - a review. In Annals of Animal Science, vol. 19, no. 3, pp. 579-593. KELLY, C. F. - BOND, T. F. 1971. Bioclimatic factors and their measurements. In A Guide to Environmental Research on Animals, pp. 7-92. Washintong, DC, USA : National Academy of Sciences.

KEY, N. - SNEERINGER, S. - MARQUARDT, D. 2014. Climate Change, Heat Stress, and U.S. Dairy Production. In USDA-ERS Economic Research, report no. 175, 39 pp. Available at: <https://www.ers. usda.gov/webdocs/publications/45279/49163_err175_summary. pdf? $=0>$.

LENDELOVÁ, J. - BOTTO, L. - SZABOVÁ, T. 2012. Effect of different cooling systems on lying time of dairy cows in cubicles with separated manure solids bedding. In Journal of Central European Agriculture, vol. 13, no. 4, pp. 717-728.

LEES, A. M. - LEA, J. M. - SALVIN, H. E. - CAFE, L. M. - COLDITZ, I. LEE, C. 2018. Relationship between rectal temperature and vaginal temperature in grazing Bos taurus heifers. In Animals, vol. 8, no. 9, pp. 156.

MONDACA, M. R. - CHOI, C. Y. - COOK, N. B. 2019. Understanding microenvironments within tunnel-ventilated dairy cow freestall facilities: Examination using computational fluid dynamics and experimental validation. In Biosystems Engineering, vol. 183, pp. 70-84.

NÉMETHOVÁ, M. - LENDELOVÁ, J. - ŠRANKOVÁ, J. - ŽITŇÁK, M. BOTTO, L.' 2020. Verification of thermo-technical characteristics of selected floor constructions for dairy cows (pilot study). In Acta Technologica Agriculturae, vol. 23, no. 2, pp. 87-91.

NORDLUND, K. V. - STRASSBURG, P. - BENNET, T. B. - OETZEL, G. R. COOK, N. B. 2019. Thermodynamics of standing and lying behavior in lactating dairy cows in freestall and parlor holding pens during conditions of heat stress. In Journal of Dairy Science, vol. 102, no. 7, pp. 6495-6507.
PINTO, S. - HOFFMANNN, G. - AMMON, C. - HEUWIESER, W. LEVIT, H. - HALACHMI, I., - AMON, T. 2019. Effect of two cooling frequencies on respiration rate in lactating dairy cows under hot and humid climate conditions. In Annals of Animal Science, vol. 19, no. 3, pp. 821-834.

ROTH, Z. 2020. Cooling is the predominant strategy to alleviate the effects of heat stress on dairy cows. In Reproduction in Domestic Animals; vol. 00, pp.1-7.

SHEIKH, A. A. - BHAGAT, R. - ISLAM, S. T. - DAR, R. R. - SHEIKH, S. A. - WANI, J. M. - DOGRA, P. 2017. Effect of climate change on reproduction and milk production performance of livestock. In Journal of Pharmacognosy and Phytochemistry, vol. 6, no. 6, pp. 2062-2064.

THOM, E. C. 1959. The discomfort index. In Weatherwise, vol. 12, no. 2, pp. 57-59.

VACULÍK, P. - JEHLIČKA, T. - KAŽIMÍROVÁ, V. - SMEJTKOVÁ, A. 2021. Water consumption in the automatic milking systems. In Acta Technologica Agriculturae, vol. 24, no. 3, pp. 136-142.

WANG, X. - GAO, H. - GEBREMEDHIN, K. G. - BJERG, B. S. - VAN OS, J. - TUCKER, C. B. - ZHANG, G. 2018a. A predictive model of equivalent temperature index for dairy cattle (ETIC). In Journal of Thermal Biology, vol. 76, pp. 165-170.

WANG, X. - GAO, H. - GEBREMEDHIN, K. G. - BJERG, B. S. - VAN OS, J. - TUCKER, C. B. - ZHANG, G. 2018b. Corrigendum to "A predictive model of equivalent temperature index for dairy cattle (ETIC)". In Journal of Thermal Biology, vol. 82, pp. 252-253.

WEST, J. W. - MILLINIX, B. G. - BERNARD, J. K. 2003. Effects of hot, humid weather on milk temperature, dry matter intake and milk yield of lactating dairy cows. In Journal of Dairy Science, vol. 86, no. 1, pp. 232-242.

WHEELOCK, J. B. - RHOADS, R. P. - VANBAALE, M. J. - SANDERS, S. R. - BAUMGARD, L. H. 2010. Effects of heat stress on energetic metabolism in lactating Holstein cows. In Journal of Dairy Science, vol. 93, no. 2, pp. 644-655.

WHEELER, E. F. 2012. Evaluating air quality in livestock housing environments. Available at: https://extension.psu.edu/ evaluating-air-quality-in-livestock-housing-environments

ZHOU, B. - WANG, X. - MONDACA, M. R. - RONG, L. - CHOI, C. Y. 2019. Assessment of optimal airflow baffle locations and angles in mechanically-ventilated dairy houses using computational fluid dynamics. In Computers and Electronics in Agriculture, vol. 165, article no. 104930. 